FACTA UNIVERSITATIS

Series: Physical Education and Sport, Vol. 16, No 3, 2018, pp. 611 - 620

https://doi.org/10.22190/FUPES180607055R

Professional article

\title{
THE SEQUENCE OF PROCEDURES \\ IN THE DEVELOPMENT OF FINE MOTOR COORDINATION THROUGH PHYSICAL ACTIVITIES AND MOVEMENT GAMES IN PRESCHOOL CHILDREN
}

\author{
UDC 796.01
}

796.11-053.3

\author{
Nebojša Randjelović ${ }^{1}$, Irena Stanišić ${ }^{2}$ Branislav Dragić1, \\ Danica Piršl ${ }^{1}, Z^{2}$ ezdan Savić ${ }^{1}$ \\ ${ }^{1}$ Faculty of Sport and Physical Education, University of Niš, Niš, Serbia \\ ${ }^{2}$ Preschool Teacher Training College, Kruševac, Serbia
}

\begin{abstract}
In order to successfully master the initial writing process that a child faces at school, it is necessary to develop fine motor coordination of the arm, hand and finger muscles. The aim of this paper is to provide the child with perceptual-motor activities, movement games as well as other physical activities that require precise movements and coordination between their two hands and arms and eyes to release the hand, hand and fingers, prepare the child for fine motor coordination and encourage initial writing. The sequence of procedures in the development of fine motor coordination as well as physical activities contributing to the development of: muscle tone, lateralization, movements of the hand and fingers, sensory observation, orientation in time and space, abilities and skills of ocular evaluation, feeling for rhythm and fine motor - visual guidance, willing control and coordination between the movement of the hand, hand and fingers, both hands and arms and eyes. The above physical activities and movement games can be used at all stages of educational work for expanding and determining children's motor skills within guided and free activities, movement games, morning physical exercise, outdoor and indoor playgrounds. Theoretical analysis of movement games and physical activities is an attempt to determine fine motor skills (preparation for initial writing) as a product-outcome, as a product of the mentioned organized activities that can provide them with specific and varied experiences, and help to develop motor and other abilities that will encourage children to write.
\end{abstract}

Key words: Fine motor skills, physical activity, movement games, preparing children for writing, eye coordination.

Received June 7, 2018 / Accepted December 27, 2018

Corresponding author: Nebojša Randjelović

University of Niš, Faculty of Sport and Physical Education, Čarnojevića 10a, 18000 Niš, Serbia

Phone: +381 18510900 •E-mail: nebojsa@fsfv.ni.ac.rs 


\section{INTRODUCTION}

In the system of versatile human development, the upbringing of a child plays an important role. From birth on, man's principles of health, physical and intellectual abilities are built up, man's movement habits are formed, speech is developed, hand motor skills and adaptation to the environment are also built (Lubysheva, 2016)

Preparing preschool children for school nowadays is one of the most current problems of contemporary pedagogy. This is because, in the practice of school education, the complexity of the first grade curriculum is observed, the introduction of new forms of teaching and new pedagogical technologies putting increasing demands on first graders are also observed (Hanova, 2015).

In this respect, the goal of pedagogues - preschool teachers in preschool institutions is "the socialization of a child and its preparation for school as the first serious social institution, by forming not only certain knowledge, skills and habits, but also by the versatile development of its personality characteristics (speech, aesthetic, physical, social, etc.)." (Belinova, 2009).

This period is also marked by the pronounced development of new motor skills. Their development is based on simpler motor patterns which occur within the first three years of life. Previously adopted motor skills with growing up become more sophisticated and more complex (Mikas, 2009).

Motor development in early childhood is mainly viewed through two fundamental developmental lines: the development of gross and fine motor skills. Rough motor skills represent the child's ability to use large muscles. It is manifested through rolling, crawling, walking, running, jumping, catching, throwing, shooting, etc. Fine motor skills are manifested through the child's ability to manipulate objects, especially with the help of fingers and hands (Bratovčić, Mehmedinović, Šarić, Teskeredžić, \& Junuzović-Žunić, 2016).

Children's motor skills development can be a "control parameter" for the acquisition of developmental functions such as: functional but also perceptual or cognitive skills. (Zrnzević \& Zrnzević, 2017)

Preparing for school, apart from the development of reading precepts, includes the development of other skills that are useful for the future adoption of writing, or the development of fine fingers motor skills. Fine motor skills develop from the earliest age, because the zones that are responsible for speech and finger movements in the brain are very close. By developing fine motor skills, the neighboring zones in the cerebral context controlling speech are encouraged to develop. Physical maturity of children for attending school contains the essential determinant of certainty, which is the degree of motor development and the ability for fine motor skills - graphomotorics. Fine motor skills is the ability to make precise, small movements with the hand while maintaining good coordination between the fingers and the eye. The compound word, graphomotorics, denotes the ability to hold a pen and write. It is an activity that is done by focusing attention and looking at the movements of the hands and fingers, in order to express, or write letters, words and sentences. Fine motor skills are characterized by small muscular movements: they usually appear in fingers (Gallahue \& Ozmun, 1998), which never act independently, but with multiple proximal parts - joints, forearms, shoulders and the spine. These parts are almost always included to ensure the stability required for your fingers to function. For sixyear-olds, the muscles of the hands are still poorly developed, and for this reason, although they are well governed by basic natural movements, such as running, jumping and 
throwing, they still do not manage to coordinate fine movements with their fingers (Antropova \& Koljcova, 1986, 17). In order for a child to achieve graphomotor and oculomotor coordination, it must pass through three phases. In the first, a child is trying to get rid of the sharp, undefined and disobedient movements of the hand. It can be said that a child is then in the stage of "painting", making curved lines of various lengths, thicknesses and direction. At this stage, the oculomotor and graphomotor actions are developed independent of one another. In the second phase, at the level of brain functions, transfers are established, so that the oculomotor and graphomotor actions are merged. Then the arm comes under the control of sight. Muscle pressure for pressure and kinesthetic movement are not yet regulated. The hand achieves skill, but it is still under the control of a visual leader. The third phase is characterized by automated graphomotor movements. Oculomotor and graphomotor coordination is a condition for reaching this highest level. In order to master writing skills, one more factor must be included through the willingness of the action, which consists of directed and controlled movements aimed at solving the task.

According to Cvetković $(2011,29-30)$, the movements of the hands are carried out by the muscles of the forearm, as well as the long and short muscles of the hand. The function of the long palm muscles is primarily designed to perform powerful and rough movements by folding the fingers, thus forming a hook shape that can engage objects or carry loads. In contrast, short palm muscles perform precise and measured movements of the fingers, and the hand becomes gentler and more plastic, and can intimately cover objects. With each finger, it becomes a very mobile, autonomous organ, which creates with the thumb a sharp tweezers for capturing small objects and performing other gentle and complex movements. The little pinky finger is more mobile than the other three fingers, thanks in particular to the larger number of muscles that move it. In addition to its basic functions, its effect increases or reduces the transversal arch of the palm. The thumb moves four long and four short muscles, which are well developed and richly innervated. The most important movements of this body are: opposition and reposition. It can be said that the use of the thumb during evolution had a decisive influence on the development of the frontal part of the brain, that is, on the development of intelligence.

Practical and motor organization of fine motor skills is a hereditary function whose speed of maturation can be influenced by environmental factors. Stapling can lead to the degradation and disruption of practice activities such as dysgraphia. Modern times are increasingly focused on the use of computers and keyboards, so disorders seen in the ability of clear, legible and organized writing can increasingly be expected in the younger generation. In some surveys, there is evidence that a large number of pre-school children are not able to pick up the fourth finger on request and willingly. It is thought to be a result of poorer exercise and the growing use of a mouse with a computer. Fine motor skills studies (Džinović-Kojić \& Kamenov, 2000, 192) researching children before enrolling in school and impacting their success in all subjects show that children with better oculomotor and graphomotor abilities achieve better success in all subjects.

As early as the 17 th century, Komenski emphasized that early childhood is the basis for the further development of man, that the action on a child should be adapted to his nature, that it learns by observing reality, and in that reality it must engage as many senses as possible (Komenski, 2000). Its natural need to be active, to move, to examine the possibilities of the objects and to manipulate them confirms the child's consistent intrinsic motivation, which determines its initiative. In this process, from the simplest to the more complex action in the environment surrounding it, a child tries to assimilate 
one's own experiences into its thought structures. The child's initiative determines its twoway action in relation to the reality and in relation to itself and its own ability to act, and then creates the conditions to transform the subject of action and cultivate its behavior. Montessori $(1955,55)$ believes that the impression from the outside world is not absorbed by the child, but by his own life.

\section{METHODS}

The object of this research are the fine motor skills of the pre-school age children, and it is conditioned by the subject of the research, i.e. pedagogical conditions influencing them. The aim of the research is to present and explain the necessary conditions and tasks that can ensure the development of fine motor skills of pre-school children in their preparation for writing. More precisely, the aim of this paper is to give practical instructions and examples that will show how a child adapts an arm, a hand and fingers through perceptual-motor activities, movement games and other physical activities that require precise movements and coordination between the arm, hand and the eyes which prepare for fine motor skills and initial writing. In order to realize this goal it was necessary to learn the concept of fine motor skills in pre-school children based on the analysis of scientific literature; to distinguish the distinctive features of the development of fine motor skills of the children of this age; to explain the necessary pedagogical conditions for their development.

By a theoretical analysis of movement games and physical activities, this paper attempts to determine fine motor skills (preparation of children for writing) as a product outcome, as a product of the mentioned organized activities among children. Examples of these activities can provide adequate and diverse specific experiences that will help children develop motor skills (gross and fine) and other abilities that will encourage them to write.

The methods applied are: analysis of pedagogical and research methods literature related to this issue, observation (within the summing up of the results of the personal experience of the author from the aspect of providing pedagogical conditions for the development of preschool children's fine motor skills), modeling of the system of methodical tasks and methodology for the application of examples of different activities in the process of training and education with the aim of realization of pedagogical conditions for the development of fine motor skills in children of this age.

The research material comprises various exercises and games that contribute to the achievement of the set goal, whereby they are only listed here, and a more detailed representation of these games and activities is omitted due to space constraints and will be presented in some other form (a manual or a monograph).

The practical significance of this research is that the above exercises and games for the development of fine motor skills can be used in the practice of pedagogues, school psychologists, parents. The application of complexes of these exercises and games can contribute to children's psychological development which enables more complete preparation of the children of this age for school. 


\section{THEORETICAL CONSIDERATIONS OF THE PROBLEM}

Koltsova under the term "fine motor skills" implies "the totality of coordinated actions of the nervous, muscular and bone system, often in cooperation with the system of vision in performing fine and accurate movements with fists, hands and legs." (Koltsova, 1993).

A range of physical activities based on precise visual control, guidance, shape and size of the movement particularly contribute to fine motor skills and the preparation for initial writing. Bearing in mind the similarity of these activities, as well as the possibility of the skills acquired through the exercise to be directly applied in the preparation for writing, there is an attempt to elaborate the whole Physical Education Methodology in the function of preparing for writing. However, despite the fact that physical activities, some more and some less, contribute to the preparation of children for school, they should not be subordinated to this goal.

The advancement of natural forms of movement, and the development of gross motor skills according to Kamenov $(2006,309)$ create the basis for the development of fine motor skills, including graphomotorics, as its component and in accordance with proximal-distal development. This is achieved by performing motivated, conscious movements and actions, indirectly or directly related to the skills required to write.

Exercises for the development of muscles of the hands and fingers, coordination of the movement, thanks to which the child's hand becomes agile and "obedient", establish the skill in moving in four directions, as well as circular movement (clockwise and vice versa), it relaxes the hand (the hand develops by opening and closing, initially slower and then faster), the games (mobile), perceptual activity as well as all other activities (bodily) that require precise movements and coordination between the arm, and the arms and the eye, are contributed to. These activities help a child manage his movements, skillfully, easily and freely, develop visual control over movements and forms of coordination of the eye and arm, which is a good basis for the adoption and the writing skills themselves.

Activities that promote faster development of fine motor skills are physical activities in which various devices and requisites are applied in different operating conditions, applying various forms of movement. In contact with devices and equipment, the child recognizes their color, shape, size and weight, and manipulates them, develops tactile and visual perceptions, as well as proprioceptive (joint-muscular) sensitivity. Performing exercises in this way a child also establishes spatial relations: up-down, front-behind, long-short, highlow, difficult-easy, oblique-right; geometric figures: circle, triangle, square, etc. Performing and encouraging the kinesthetic attention of the child leads to a state of focus on the body's movement and balance. At the same time, activities and games develop the sense of one's own movement, one's own body in space as well as oneself in relation to other objects and participants. There are activities that require the perception of the spatial arrangement of devices and props, their memory and reproduction, i.e., one's own performance according to a class teacher role model.

Effective means of developing fine motor skills in the teaching process are games with fingers - special exercises for the development of fine muscular skills of fingers. They train the accuracy of movement responses, develop coordination of the movements, and help to focus attention (Sechkina, 2008).

Different finger games can be applied, the stimulation of various gestures (rain falling, apples picking) and nicknames "Kolarić - Panic" as a break, a change in activity, a game that exercises and respects traditional culture. These games are simple at first glance. They 
develop a variety of forms of attention, concentration and increase the sensitivity of the eyes. The choice of these games can be called - Manipulative games. Such games include games such as Engines, Sun, Forest, Stone, Orange, Cat, Spinoza, Elephant Race, and Paper Shooting.

Thanks to maturation and various physical activities and exercises through the game, the movements of the hands become more skilled, safer and more free, and the child is more able to manage them quickly, easily and at will, without the difficulty of changing direction. In the year before going to school, the strength and skill of the hand increase, the dominant hand, in which a significant role is exercised. It consists of carrying out deliberate, specialized movements and the development of accuracy in carrying out certain actions with the dominant hand, but also with both hands.

The procedures for training children for the development of fine motor skills through movement and physical activity can be seen through the following components:

Muscle tone is determined at the level of tension between the flexor and the extensor around one or more joints (agonists and antagonists). In the elbow and fist joints there is unevenness. This unevenness of the muscle tension involved in the act of writing speaks of an uneven basis that the impulse for movement should organize into the act of graphomotor shaping. Within the organization of work in the institution children are provided with the possibility of using large muscles in all forms of movement games, dances, various forms of movement and other forms of physical activity. The most commonly used exercises are the development of the muscles of the arm, forearm, shoulder belt, back, abdominal and muscle legs through the movements: raising and lowering, spreading and collecting hands and performing circular movements (rowing, flying, spraying, swinging movements); tilting the body back and forth, aside from different positions (standing, sitting, squatting); lifting the trunk from a supine position, the trunk to legs and legs to trunk; lifting the trunk from a prone position, the trunk to legs and legs to trunk; lifting the trunk from the lying position on the abdomen, hands aside or on the back of the head; walking in different ways across different surfaces, etc.

Lateralization is uneven, it is difficult to perform alternate movements in the gesticular space, and in the performance of the graphomotor sequence it is slow and uneven. The dominant side should be determined in such a way that the child is given the task of intertwining his fingers. The thumb from above points to the dominance of the hand.

The mobility of hands and fingers - especially each finger, thumb and index finger, thumb and finger and all fingers, is achieved by activities that have a playing character. Those are: games with fingers; rock paper scissors; games with marbles; rolling balls and small balls; raising and catching bags with sand or beans; throwing the ball in the air, riding a ball; hitting balloons with plastic bottles, dribbling ball tight to the rope; exercises with rope and scarf, balancing; throwing frisbees, etc.

The development of sensory perception is achieved through perceptive activities. The devices, props, shape, color, weight, material from which they are made, size, position, mutual differences and similarities are perceived. In addition to the activities, various games are also used, which require precise movements and coordination, memory, and analyticalsynthetic procedures are being developed. On this occasion, attention and concentration develop as well. These are the activities: taking balls of different sizes, big beach balls, tennis balls, soccer balls, a deflated ball, high-pitched ball, a table tennis ball; application of hoops, ropes, rods, sandbags, flags, stretchers; running with touching left hand, right leg, head; pantomime - body language expresses traits (brave, joyful, sad). 
Orientation exercises in space includes the development of concepts related to the distance of objects (far, near ...), their position in space (above, below, between, around, in the middle, on, etc.), and spatial relationships (here, there). To this purpose, activities in which obstacle paths (polygons) are placed where children move in various directions are recommended, climbing, descending, jumping, raising, carrying objects, wandering, depending on the tasks that the educator has set. Changing the size of the space in which the child moves requires the child to get to know geometric bodies, the spatial relationships and the mutual position of the device and the props in space. Time orientation refers to activities during the day and their duration. It is stated through the following activities: organized walking in the train, circle, in a pair; throwing in the space, high, low, right, bottom, up, through the legs; throwing in time, fast slow, throwing while running, throwing during a jump, tossing through the force, very strongly with both hands, with one hand, very weak, strongly with left hand, strongly with right hand; throwing from the chest, from the sitting position, sitting facing his pair and shooting over his head; swing at the side shoot, jump and shoot, from the back, using both hands, changing hands, jump off shoot, through the legs, backwards with both hands, backwards through the legs with both hands, from the top, from the bottom, sitting on the floor; with a blanket running to the other end of the sports hall, hide in their blanket, put the blanket over the shoulder and run as a pair.

Developing skills and ability of the random evaluation is of course important. The inadequate coordination of the fingers, hands, arms, and forearms is reflected in the skill. There are plenty of exercises that develop skills and random evaluations such as: throwing frisbees in pairs; throwing the ball, clap hands and grab the ball; throw the ball, clap hands behind back and catch the ball; throw the ball, clap hands under legs and catch the ball; throw the ball, fold around axis and grab the ball; throw the ball, touch the nose and grab the ball; throw the ball, touch the floor and grab the ball; throw the ball against the wall, clap hands and grab the ball; throwing foam frisbees at foam rods; skipping the rope in pairs; passing the ball with a scarf in a pair; shooting objects with some props; rolling the ball, etc.

Developing feelings for rhythm, harmony of rhythmic movements and symmetry is achieved by physical activities in which rhythmic movements of the arm and the leg occur. They are developed by many physical activities, some of which are: exercises for the development of muscle groups with rhythmic counting; movement games accompanied by music; spinning under the rope, the burpee box; traditional games with fingers; folk games, rhythmic-dance games, etc.

Exercises for the development of fine motor skills - visual guidance, willing control and coordination between the movement of the hand, hand and fingers, both hands, arms and eyes, their rhythm, strength, tempo, space and accuracy. These are the following games: passing ball, balloon, Frisbee; kicking the ball; dribbling the ball around the obstacles, between the obstacles and under the obstacle; shooting of immobile targets in place and while moving; throwing balls, bags, Frisbees; catching balls, bags; dart playgrounds (shooting the target darts with arrows with rubber finish); putting a hoop on a rack; dribbling a ball with a rod between the cones; shooting a ball into a hoop horizontally set or through a hoop vertically set. 


\section{DISCUSSION}

The above activities and many others can be used at all stages of the educational process for expanding and determining children's motor skills. The work method and application depends on the ability of children, creativity, and motivation to work. In addition to focused activities that shift the frontal, group and individual forms of work, when required by the individualization of the procedure, other types of open-air activities in the form of playrooms, leisure activities, morning exercises, which children will be happy to use, are suitable. In order to arouse the interest in the child in the initial period, it is important to turn motor motions into interesting games using devices, props and observing certain rules.

They can be applied throughout the entire physical education class. In the preparatory part of the class motor skills can be developed during warm up exercises that strengthen the muscles of the fingers and the hand (fingers gymnastics, palms massage). Each exercise is performed by counting or following the verses read by the teacher, and the children repeat after him or her. In the main part of the class, motor skills are developed by means of a relay with small objects (cubes, tennis balls, hedge balls, etc.), using movement games with elements of basketball, volleyball, etc. In the final part of the class one should use games with fingers (e.g. paper, stone, scissors), pantomime, etc. (Chepiga, 2018).

Movement games that can have content, or even games without it, meet the basic need of a pre-school age child for movement and thus help his overall physical development, the development of its motor apparatus, coordination and speed of movement, skill, coherence and beauty. There are a large number of games that can be arranged with children in different variants. This implies the possibility of organizing targeted activities through the game, which in some ways ensures continuity in the education system at the pre-school institution at all ages. Sikimic (1999) considers that in this way work requirements are aligned with the children's abilities, increasing the achievement, quality and efficiency of the educational activities.

While playing, children are engaged to the maximum, using acquired knowledge, experience and skills. They are very patient, which is rarely observed in some other activities. During play children are, according to Vigotsky (1996), exploring the world around them and their own possibilities, developing their abilities: perceptual-motor, intellectual, socioemotional, communication and creative, which in time become more open to next activities, within the "future development zone".

There are many ways that children learn through their games and prepare for the development of fine motor skills and initial writing activities. This implies the application of various types of movement games described in this paper, which can be applied in working with preschool children. These movement games, which are in the function of writing, include restricted activities, first of all in the domain of motor skills, from the development of gross motor skills, through the development of fine motor skills, handcoordination, to the improvement of the child's graphomotor capabilities, or the period of reaching readiness for the initial writing.

The recommendation of the movement games that can be practiced within the stated goal is to use: Balloon punching, Balloon Juggling, Balloon Tennis, Catch the Ball In the Basket, Basketball Game, Meta Crawl, Throw and Catch, Guess shooting, Golf throw, Cardboard spear, Crab Walk, Run Away from Ball, Golf balls, Throwing in the Target, Tolling balls and Catch the small balloon. 


\section{CONCLUSION}

Contemporary teaching practice shows tendencies for improving the educational process, enriching it with new content, methods and forms of work. Each innovation, even the one shown in this paper, aims to become a practice. The given examples of the use of these movement games, the forms of movement and other physical activities in the development of fine motor skills and initial writing, are only a signpost of the possible innovation and enrichment of the content of work.

The presented methodological instructions are based on a well-chosen theoretical context of the problem of development of fine motor skills, hand-eye coordination (preparation for the initial writing), in relation to the principles and characteristics of the child's development, the specificity of the structural and functional formation of his nervous-muscular system, the gradual process of the children's growing up, and many others. The development of psychomotor readiness of children for the adoption of the graphic component of writing, through the improvement of natural forms of movement, the development of gross and fine motor skills, lateralization exercises, improvement of movement, coordination of movement, all the way to the achievement of willing coordinated movements of the child. This selected theoretical context is reinforced, in the form of recommendations, examples of activities and games to be offered to children, with the possibility of using different devices and props, and various didactic and methodical organizational forms of work.

Preparing the hand of a preschool child should be carried out systematically. It demands allocation of a certain amount of time, and also introduction into the daily regime. It is desirable to start working as soon as possible and not later than one year before going to school. The most optimal variant for success is the joint action of pedagogues and parents. (Gurkina, 2015).

\section{REFERENCES}

Antropova, M.V., \& Koljcova, M.M. (1986). Psihofiziološka zrelost dece (Psychophysiological maturity of children). Belgrade: Zavod za udžbenike i nastavna sredstva. In Serbian

Belinova, N.V. (2009). Diskursivnый podhod k sisteme doškolınogo obrazovaniя (Discursive approach to the system of preschool education). Vestnik Vyatskogo Gosudarstvennogo Gumanitarnogo Universiteta, 2, 4346. In Russian

Bratovčić, V., Mehmedinović, S., Šarić, E., Teskeredžić, A., \& Junuzović-Žunić, L. (2016). Razlike u vještinama fine i grube motorike između četverogodišnjaka koji su obuhvaćeni i koji nisu obuhvaćeni predškolskim odgojem i obrazovanjem (Differences in gross motor and fine motor skills between four year old children). $7^{\text {th }}$ International Scientific-Professional Conference "Improving the Quality of Life of Children and Youth", (pp. 1-8). Tuzla: Papir-Karton. dela

Cvetković, N. (2011). Vežbanje sa osnovama lokomotornog sistema i motoričkog učenja (Exercising with the basics of locomotor system and motor learning). Kragujevac: Grafostil. In Serbian

Chepiga, M.G. (2018). Razvitie melkoй motoriki na urokah fizičeskoй kulьturы v načalьnoй škole (The development of fine motor skills in physical education classes in elementary school). Materials of the Scientific and Scientific-Methodical Conference. (pp. 77-78). Krasnodar: Kuban State University of Physical Education, Sports and Tourism. In Russian

Džinović-Kojić, D., \& Kamenov, E. (2000). Fizička zrelost dece za polazak u školu (Physical maturity of children for school). Zajednica Viših škola za obrazovanje vaspitača Republike Srbije. In Serbian

Gallahue D.L., \& Ozmun J.C. (1998) Understanding motor development. Infants, children, adolescents, adults (4th Ed.). Boston, MA: McGraw-Hill.

Gurkina, Z.S., \& Buchneva, I.I. (2015). Razvitie melkoй motoriki ruk doškolınika - pervыm stepen k ego intellektualınomu razvitiю pri podgotovke k školnomu obučenie (The development of fine motor skills of a 
preschooler is the first step towards his intellectual development in preparation for schooling). Doshkolnoe obrazovanie: Opyt, Problemy, Perspektivy Razvitiya, 3 (6), S. 35-37.

Hanova, T.G. (2015). Sovremennoe doshkolnoe detstvo: problemy i perspektivy (Modern pre-school childhood: problems and prospects). Vestnik Mininskogo Universiteta, 2 (10), S. 31

Kamenov, E. (2006). Vaspitno-obrazovni rad u pripremnoj grupi dečjeg vrtića - teorija i praksa (Educational work in the preparatory group of kindergartens - Theory and practice). Novi Sad: Zmaj. In Serbian

Komenski, J.A. (2000). Maternity school. Belgrade: Zavod za udžbenike i nastavna sredstva. In Serbian

Koltsova, M.M. (1993). Dvigatelnaya aktivnost $i$ razvitie funkciy mozga (Motor activity and development of brain functions). Moscow: Pedagogika. In Russian

Lubysheva, L.I. (2016). Sportizaciya obscheobrazovatelnyh shkol: konceptualnye osnovy i tehnologicheskie resheniya (Sport permeation of secondary schools: Conceptual framework and technological solutions). Fizicheskaya kultura: Vospitanie, Obrazovanie, Trenirovka, 1, S. 5-8. In Russian

Mikas, D. (2009). Sportski programi i socijalna kompetencija djece predškolske dobi (Sports programs and social competences of preschool children). Paediatria Croatica, 53 (1), 227-232. In Croatian

Montessori, M. (1995). The absorbent mind. New York: Holt.

Sechkina, O.K. (2008). Formirovanie psihomotornyh svoystv rebenka v rannem vozraste kak vazhnyy faktor razvitiya psihomotoriki (The formation of psychomotor properties of a child at an early age as an important factor in the development of psychomotor activity). Sovremennyy Mir i Obrazovanie, 276-279.

Sikimić, LJ. (1999). Dečje igre (Children's' games). Belgrade: Kreativni centar. In Serbian

Vigotskiy L.S. (1996). Sabrana dela (Collected works). Belgrade: Zavod za udžbenike i nastavna sredstva. In Serbian

Zrnzević, N., \& Zrnzević, J. (2017). Programmed physical education teaching and its effects on students' motor skills. Facta Universitatis Series Physical Education and Sport, 15(3), 501-512.

\section{REDOSLED POSTUPAKA U RAZVOJU FINE MOTORIKE FIZIČKIM AKTIVNOSTIMA I POKRETNIM IGRAMA DECE PREDŠKOLSKOG UZRASTA}

Za uspešno ovladavanje početnog nivoa procesa pisanja koje dete očekuje u školi, potrebno je da se razvije fina motorika mišića ruke, šake i prstiju. Pripremi za pisanje posebno doprinosi niz fizičkih aktivnosti, budući da zahtevaju preciznu vizuelnu kontrolu pokreta, kao i vođenje računa o obliku $i$ veličini. Imajući u vidu srodnost ovih aktivnosti, kao i mogućnost da se veštine stečene fizičkim aktivnostima neposredno primene u pripreni za pisanje, ima pokušaja da se razradi čitava Metodika fizičkog vaspitanja u funkciji pripreme za početno pisanje. Cilj ovog rada je da dete putem perceptivno - motornih aktivnosti, pokretnih igara kao i drugih fizičkih aktivnosti koje zahtevaju precizne pokrete i koordinaciju između dve ruke i ruke i očiju oslobodi ruku, šaku i prste, pripremi dete za finu motoriku i podstakne na početno pisanje. Prikazan je redosled postupaka u razvoju fine motorike, kao $i$ fizičkih aktivnosti koje doprinose razvoju: tonusa mišića, lateralizovanosti, pokretnjivosti šake i prstiju, čulnog opažanja, orjentacije u vremenu i prostoru, vizuelnih sposobnosti $i$ spretnosti, osećaja za ritam i fine motorike - vizuelnog usmeravanja, voljne kontrole i koordinacije između pokreta ruke, šake i prstiju, obe ruke i ruku i očiju. Navedene fizičke aktivnosti i pokretne igre mogu se upotrebiti u svim etapama vaspitno - obrazovnog rada za proširivanje i utvrđivanje dečijih motoričkih sposobnosti u okviru usmerenih i slobodnih aktivnosti, pokretnih igara, jutarnjeg telesnog vežbanja, igraonica na otvorenom $i$ zatvorenom. Teorijskom analizom pokretnih igara i fizičkim aktivnostima dat je pokušaj da se fina motorika (priprema za početno pisanje) odredi kao produkt ishod, kao proizvod pomenutih organizovanih aktivnosti koje im mogu pružiti specifična i raznovrsna iskustva, i pomoći da se razviju motoričke i druge sposobnosti koje će ih podstaći na pisanje..

Ključne reči: fina motorika, fizičke aktivnosti, pokretne igre, priprema dece za pisanje, koordinacija oko- ruka 